\title{
THE MEASUREMENT OF GLOMERULAR FILTRATION. THE CRE- ATININE, SUCROSE AND UREA CLEARANCES IN SUBJECTS WITH RENAL DISEASE ${ }^{1}$
}

\author{
By ALEXANDER W. WINKLER ${ }^{2}$ AND JOSÉ PARRA 3 \\ (From the Department of Internal Medicine, Yale University School of Medicine, and the \\ Medical Service of the New Haven Hospital, New Haven)
}

(Received for publication June 26, 1937)

In a previous communication (9) the manner of variation of creatinine, sucrose, and urea clearances was studied in a group of subjects without renal disease. The method involved the determination of these three clearances simultaneously in consecutive time intervals under varying conditions of urine flow. It was concluded from their behavior that change in glomerular filtration was an underlying common factor responsible for their variation, but that each one of the three clearances individually was subject to special perturbing factors.

In this paper these observations are extended to include a group of subjects with conditions affecting the renal status.

\section{MATERIALS AND METHODS}

The subjects of these investigations were patients on the medical wards of the New Haven Hospital. Clearances of creatinine, urea and in many instances sucrose, were determined in two or more consecutive periods. The conduct of the experiments, the methods of chemical analysis, and the mode of calculating clearances are all described in the preceding paper (9).

\section{RESULTS}

\section{(A) General observations}

In Table I are presented the data from 11 patients who, in spite of conditions which may have affected the vascular system or the kidneys, had no significant reduction of their clearances. In Table II are presented the studies of 11 other pa-

1 This investigation was aided by a grant from the Fluid Research Fund of Yale University, School of Medicine.

2 Alexander Brown Coxe Fellow.

${ }^{3}$ Fellow of the University of Madrid, and Honorary Fellow of Yale University. tients whose renal or vascular disease was associated with marked reduction of clearances.

In Table I there is no significant difference between the behavior of the clearances of these subjects and the behavior of strictly normal subjects. The creatinine clearance declines with time, both absolutely and relative to the sucrose clearance, in Exepriments I, II, III, IV and VII (Figure $1 A$ ). The variation of the creatinine:

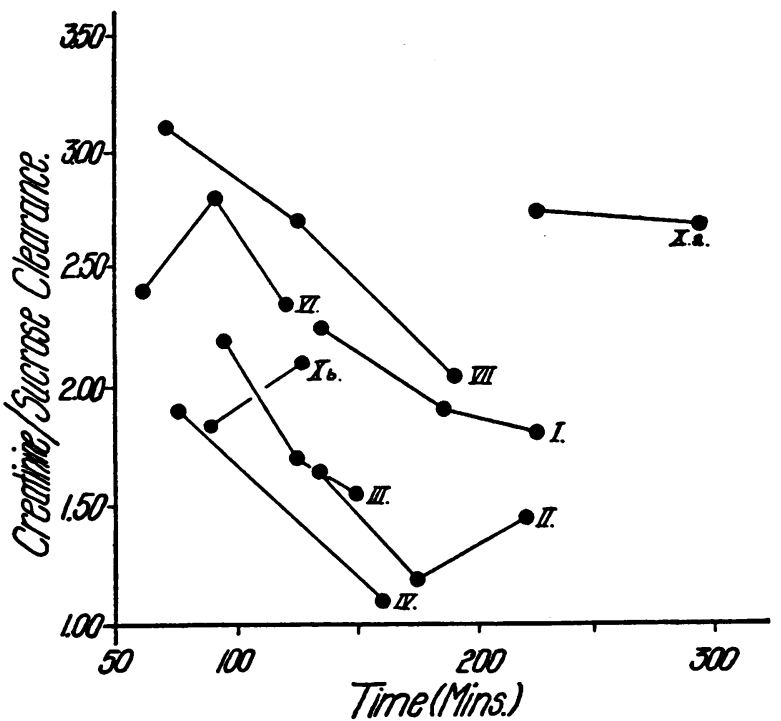

Fig. 1A. Variation of Creatinine: Sucrose Ratio with Time in Subjects without Depression of ClearANCES

sucrose ratio is irregular in Experiments VI, Xa and $\mathrm{Xb}$. The variations of the creatinine: urea ratio (Figure $1 B$ ) are less consistent. The ratio declines with time in Experiments I, IV, VIII, IX and XI, and shows no significant change in Experiments II, VI, $\mathrm{Xa}$ and $\mathrm{Xb}$. In Experiments III, $V$ and VII the creatinine: urea ratio actually rises. During the course of the three experiments in which the creatinine: urea ratio rises the urea clearance itself declines and the 
TABLE I $\dagger$

Subjects with diseases affecting the kidneys but with creatinine clearances greater than $80 \mathrm{cc}$. per minute

\begin{tabular}{|c|c|c|c|c|c|c|c|c|c|c|c|c|c|c|}
\hline \multirow{2}{*}{$\underset{\text { ber }}{\text { Num- }}$} & \multirow{2}{*}{ Nature of case } & \multirow{2}{*}{ Period } & \multirow{2}{*}{ Dose } & \multirow{2}{*}{ Time } & \multirow{2}{*}{ Urine } & \multicolumn{3}{|c|}{ Concentration in serum } & \multicolumn{3}{|c|}{ Clearance } & \multicolumn{3}{|c|}{ Clearance ratio } \\
\hline & & & & & & c & $\mathbf{s}$ & U & c & $\mathbf{s}$ & $\mathrm{U}$ & $\mathrm{c} / \mathrm{s}$ & $s / U \mid$ & $\mathrm{C} / \mathrm{U}$ \\
\hline I & $\begin{array}{l}\text { Toxemia of pregnancy, de- } \\
\text { livered; hypertension } \\
\text { F., } 32 \text { years, } 88 \mathrm{kgm} \text {. }\end{array}$ & $\begin{array}{l}1 \\
2 \\
3\end{array}$ & $\begin{array}{c}\text { grams } \\
15\end{array}$ & \begin{tabular}{|c|} 
minutes \\
134 \\
184 \\
227
\end{tabular} & $\begin{array}{c}c c . \text { per } \\
\text { minute } \\
2.5 \\
1.8 \\
4.3\end{array}$ & \begin{tabular}{|c|}
$\underset{\text { merm. }}{\text { pernt }}$ \\
14.0 \\
10.8 \\
9.5
\end{tabular} & $\begin{array}{c}\text { mgm. } \\
\text { per cent } \\
143 \\
97 \\
67\end{array}$ & $\begin{array}{c}\underset{\text { mgm. }}{\text { per cent }} \\
12.5 \\
12.5 \\
12.3\end{array}$ & $\begin{array}{c}c c \text { per } \\
\text { minute } \\
248 \\
209 \\
197\end{array}$ & $\begin{array}{c}c c \text { per } \\
\text { minute } \\
111 \\
110 \\
108\end{array}$ & $\begin{array}{c}c c . \text { per } \\
\text { minute } \\
46 \\
45 \\
45\end{array}$ & $\begin{array}{l}2.2 \\
1.9 \\
1.8\end{array}$ & $\begin{array}{l}2.4 \\
2.6 \\
2.4\end{array}$ & $\begin{array}{l}5.4 \\
4.7 \\
4.4\end{array}$ \\
\hline II & $\begin{array}{l}\text { Progressive muscular } \\
\text { atrophy, arteriosclerosis } \\
\text { M., } 51 \text { years, } 63 \mathrm{kgm} \text {. }\end{array}$ & $\begin{array}{l}1 \\
2 \\
3\end{array}$ & 15 & $\begin{array}{l}135 \\
175 \\
220\end{array}$ & $\begin{array}{l}2.6 \\
2.1 \\
2.6\end{array}$ & $\begin{array}{l}18.4 \\
17.1 \\
16.1\end{array}$ & $\begin{array}{r}140 \\
106 \\
79\end{array}$ & $\begin{array}{l}18.8 \\
18.7 \\
18.6\end{array}$ & $\begin{array}{l}153 \\
109 \\
100\end{array}$ & $\begin{array}{l}92 \\
82 \\
68\end{array}$ & $\begin{array}{l}49 \\
38 \\
33\end{array}$ & $\begin{array}{l}1.7 \\
1.2 \\
1.5\end{array}$ & $\begin{array}{l}1.9 \\
2.2 \\
2.1\end{array}$ & $\begin{array}{l}3.1 \\
2.9 \\
3.0\end{array}$ \\
\hline III & $\begin{array}{l}\text { Nephrotic syndrome } \\
\text { F., } 16 \text { years, } 60 \text { kgm. }\end{array}$ & $\begin{array}{l}1 \\
2 \\
3\end{array}$ & 10 & $\begin{array}{r}95 \\
124 \\
152\end{array}$ & $\begin{array}{l}3.9 \\
1.8 \\
2.2\end{array}$ & $\begin{array}{l}13.1 \\
14.0 \\
14.0\end{array}$ & $\begin{array}{r}150 \\
112 \\
86\end{array}$ & $\begin{array}{l}7.8 \\
7.6 \\
7.6\end{array}$ & $\begin{array}{l}221 \\
122 \\
154\end{array}$ & $\begin{array}{l}81 \\
58 \\
50\end{array}$ & $\begin{array}{r}113 \\
48 \\
52\end{array}$ & $\begin{array}{l}2.2 \\
1.7 \\
1.5\end{array}$ & $\begin{array}{l}0.7 \\
1.2 \\
1.5\end{array}$ & $\begin{array}{l}2.0 \\
2.5 \\
3.0\end{array}$ \\
\hline IV & $\begin{array}{l}\text { Nephrotic syndrome } \\
\text { F., } 16 \text { years, } 80 \text { kgm. }\end{array}$ & $\begin{array}{l}1 \\
2\end{array}$ & 10 & $\begin{array}{r}75 \\
160\end{array}$ & $\begin{array}{l}3.4 \\
1.3\end{array}$ & $\begin{array}{l}12.3 \\
12.6\end{array}$ & $\begin{array}{l}75 \\
42\end{array}$ & 22.4 & $\begin{array}{l}185 \\
100\end{array}$ & $\begin{array}{l}98 \\
91\end{array}$ & $\begin{array}{l}49 \\
33\end{array}$ & $\begin{array}{l}1.9 \\
1.1\end{array}$ & $\begin{array}{l}2.0 \\
2.8\end{array}$ & $\begin{array}{l}3.8 \\
3.0\end{array}$ \\
\hline V & $\begin{array}{l}\text { Arteriosclerosis } \\
\text { M., } 41 \text { years, } 75 \text { kgm. }\end{array}$ & $\begin{array}{l}1 \\
2 \\
3 \\
4 \\
5\end{array}$ & 10 & $\begin{array}{l}119 \\
163 \\
223 \\
281 \\
403\end{array}$ & $\begin{array}{l}5.1 \\
2.9 \\
1.5 \\
1.2 \\
0.7\end{array}$ & $\begin{array}{r}15.5 \\
14.1 \\
13.2 \\
12.2 \\
9.6\end{array}$ & & $\begin{array}{l}5.9 \\
5.9 \\
6.8 \\
8.0 \\
9.7\end{array}$ & $\begin{array}{r}98 \\
109 \\
109 \\
110 \\
93\end{array}$ & & $\begin{array}{l}62 \\
64 \\
49 \\
41 \\
29\end{array}$ & & & $\begin{array}{l}1.6 \\
1.7 \\
2.2 \\
2.7 \\
3.2\end{array}$ \\
\hline VI & $\begin{array}{l}\text { Acute glomerulonephritis, } \\
\text { subsiding } \\
\text { M., } 15 \text { years, } 65 \mathrm{kgm} \text {. }\end{array}$ & $\begin{array}{l}1 \\
2 \\
3\end{array}$ & 5 & $\begin{array}{r}59 \\
91 \\
121\end{array}$ & $\begin{array}{l}4.5 \\
5.1 \\
3.6\end{array}$ & $\begin{array}{l}9.0 \\
6.6 \\
5.4\end{array}$ & $\begin{array}{r}100 \\
62 \\
52\end{array}$ & $\begin{array}{l}9.0 \\
9.1 \\
8.8\end{array}$ & $\begin{array}{l}264 \\
256 \\
224\end{array}$ & $\begin{array}{r}111 \\
91 \\
95\end{array}$ & $\begin{array}{r}114 \\
107 \\
86\end{array}$ & $\begin{array}{l}2.4 \\
2.8 \\
2.4\end{array}$ & $\begin{array}{l}1.0 \\
0.9 \\
1.1\end{array}$ & $\begin{array}{l}2.3 \\
2.4 \\
2.6\end{array}$ \\
\hline VII & $\begin{array}{l}\text { Arteriosclerosis, } \\
\text { diabetes mellitus } \\
\text { M., } 62 \text { years, } 67 \mathrm{kgm} .\end{array}$ & $\begin{array}{l}1 \\
2 \\
3\end{array}$ & 5 & $\begin{array}{r}68 \\
123 \\
188\end{array}$ & $\begin{array}{l}1.8 \\
0.7 \\
0.6\end{array}$ & $\begin{array}{l}9.4 \\
6.5 \\
5.3\end{array}$ & $\begin{array}{r}100 \\
65 \\
40\end{array}$ & $\begin{array}{l}12.7 \\
13.4 \\
13.8\end{array}$ & $\begin{array}{l}219 \\
133 \\
147\end{array}$ & $\begin{array}{l}71 \\
49 \\
71\end{array}$ & $\begin{array}{l}56 \\
32 \\
29\end{array}$ & $\begin{array}{l}3.1 \\
2.7 \\
2.1\end{array}$ & $\begin{array}{l}1.3 \\
1.5 \\
2.5\end{array}$ & $\begin{array}{l}3.9 \\
4.2 \\
5.1\end{array}$ \\
\hline VIII & $\begin{array}{l}\text { Diabetes insipidus } \\
\text { M., } 21 \text { years, } 63 \text { kgm. }\end{array}$ & $\begin{array}{l}1 \\
2 \\
3 \\
4\end{array}$ & 10 & $\begin{array}{l}20 \\
50 \\
73 \\
95\end{array}$ & $\begin{array}{l}16.8 \\
20.0 \\
26.1 \\
12.8\end{array}$ & $\begin{array}{l}28.6 \\
21.7 \\
18.8 \\
16.0\end{array}$ & & $\begin{array}{l}8.0 \\
7.0 \\
6.5 \\
7.6\end{array}$ & $\begin{array}{l}211 \\
167 \\
200 \\
129\end{array}$ & & $\begin{array}{r}86 \\
127 \\
159 \\
77\end{array}$ & & & $\begin{array}{l}2.5 \\
1.3 \\
1.3 \\
1.7\end{array}$ \\
\hline IX & $\begin{array}{l}\text { Acute focal nephritis } \\
\text { M., } 23 \text { years, } 74 \mathrm{kgm} \text {. }\end{array}$ & $\begin{array}{l}1 \\
2 \\
3\end{array}$ & 10 & $\begin{array}{l}157 \\
193 \\
225\end{array}$ & $\begin{array}{l}2.2 \\
5.7 \\
8.5\end{array}$ & $\begin{array}{l}17.9 \\
15.5 \\
13.5\end{array}$ & & $\begin{array}{l}16.3 \\
15.7 \\
15.5\end{array}$ & $\begin{array}{l}214 \\
202 \\
197\end{array}$ & & $\begin{array}{l}55 \\
69 \\
72\end{array}$ & & & $\begin{array}{l}3.9 \\
2.9 \\
2.7\end{array}$ \\
\hline $\mathbf{x}$ & $\begin{array}{l}\text { Acute glomerulonephritis } \\
\text { M., } 16 \text { years, } 75 \text { kgm. }\end{array}$ & $\begin{array}{l}1 \ddagger \\
2 \\
1 \pi \\
2\end{array}$ & $\begin{array}{l}10 \\
10\end{array}$ & $\begin{array}{r}195 \\
300 \\
70 \\
127\end{array}$ & $\begin{array}{l}2.8 \\
2.4 \\
3.2 \\
3.3\end{array}$ & $\begin{array}{r}8.7 \\
7.1 \\
13.9 \\
15.5\end{array}$ & $\begin{array}{r}77 \\
66 \\
147 \\
117\end{array}$ & $\begin{array}{l}25.0 \\
26.0 \\
21.9 \\
21.9\end{array}$ & $\begin{array}{l}235 \\
211 \\
109 \\
141\end{array}$ & $\begin{array}{l}85 \\
78 \\
60 \\
67\end{array}$ & $\begin{array}{l}46 \\
40 \\
47 \\
57\end{array}$ & $\begin{array}{l}2.8 \\
2.7 \\
1.8 \\
2.1\end{array}$ & \begin{tabular}{l|}
1.9 \\
2.1 \\
1.3 \\
1.2
\end{tabular} & $\begin{array}{l}5.1 \\
5.3 \\
2.3 \\
2.5\end{array}$ \\
\hline $\mathbf{X I}$ & $\begin{array}{l}\text { Nephrosclerosis } \\
\text { M., } 60 \text { years, } 56 \text { kgm. }\end{array}$ & $\begin{array}{l}1 \\
2 \\
3 \\
4 \\
5\end{array}$ & 10 & $\begin{array}{l}168 \\
211 \\
245 \\
298 \\
367\end{array}$ & $\begin{array}{r}12.7 \\
17.2 \\
10.0 \\
8.2 \\
6.7\end{array}$ & $\begin{array}{r}10.9 \\
10.2 \\
9.2 \\
8.5 \\
8.2\end{array}$ & & $\begin{array}{l}15.2 \\
* \\
21.0 \\
20.3 \\
20.3\end{array}$ & $\begin{array}{r}100 \\
169 \\
108 \\
97 \\
82\end{array}$ & & $\begin{array}{l}20 \\
32 \\
28 \\
30\end{array}$ & & & $\begin{array}{l}5.0 \\
* \\
3.4 \\
3.5 \\
2.8\end{array}$ \\
\hline
\end{tabular}

* Urea injected intravenously.

†C stands for creatinine, $S$ for sucrose, $U$ for urea nitrogen. All times are calculated to the middle of the period, and all serum concentration figures are extrapolated values. Italic type indicates that the dose of creatinine was administered intravenously.

$\$$ January 6. 
urine flow falls off to rates of 2 cc. per minute or less. It is possible that in these three instances the usual drop of the creatinine clearance relative to the other clearances, normally reflected in a drop in the creatinine : urea ratio, is masked by a rise in the ratio brought about through the variation of urea clearance with urine flow at these levels. Certainly, taken as a whole, the behavior of the clearances in this group of subjects is very similar to that of normal subjects (9). The drop in the creatinine: sucrose and creatinine: urea ratios is not correlated with the particular type of case involved. Thus Experiments III and IV, true " nephrosis," or inactive chronic glomerulonephritis, with profuse albuminuria, cylindruria, and edema, showed the decline to a marked extent, although obviously possessing a renal lesion of some sort. Experiments I and VII had varying degrees of general vascular disease and showed the decline, yet Case $\mathrm{V}$ with equal vascular involvement did not. Experiments VI, VIII and IX all probably had quite normal kidneys, yet only two of the three showed this effect.

In the variation of their clearances with urine

TABLE II $\dagger$

Subjects with renal disease and creatinine clearances less than $80 \mathrm{cc}$. per minute

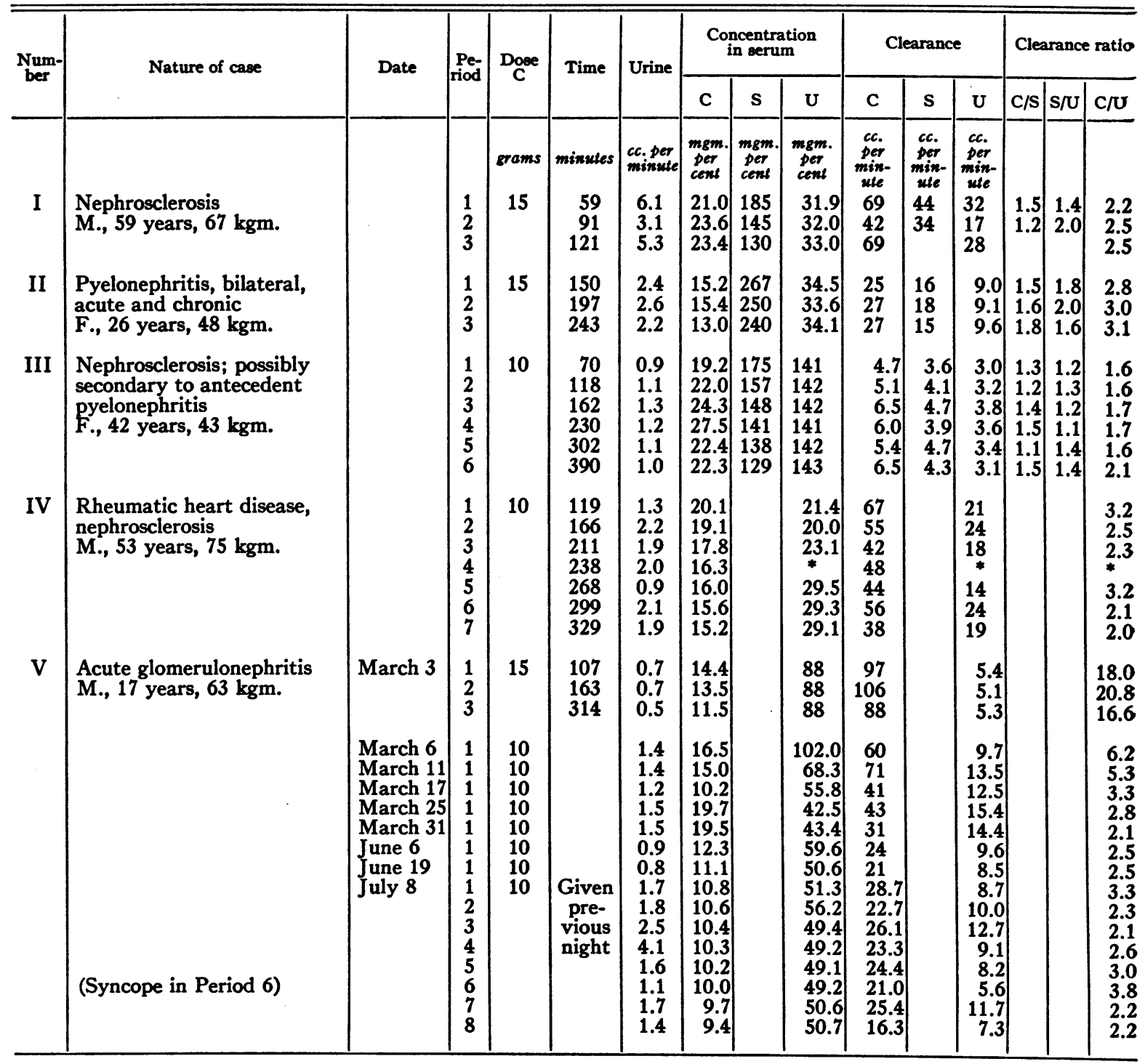


TABLE II-Continued

\begin{tabular}{|c|c|c|c|c|c|c|c|c|c|c|c|c|c|c|c|}
\hline \multirow{2}{*}{$\underset{\text { ber }}{\text { Num- }}$} & \multirow{2}{*}{ Nature of case } & \multirow{2}{*}{ Date } & \multirow{2}{*}{$\begin{array}{l}\text { Pe- } \\
\text { riod }\end{array}$} & \multirow{2}{*}{ Dose } & \multirow{2}{*}{ Time } & \multirow{2}{*}{ Urine } & \multicolumn{3}{|c|}{$\begin{array}{c}\text { Concentration } \\
\text { in serum }\end{array}$} & \multicolumn{3}{|c|}{ Clearance } & \multicolumn{3}{|c|}{ Clearance ratio } \\
\hline & & & & & & & c & $\mathbf{s}$ & U & c & $\mathrm{s}$ & U & $\mathrm{c} / \mathrm{s}$ & $\mathrm{s} / \mathrm{U}$ & $\mathrm{C} / \mathrm{U}$ \\
\hline VI & $\begin{array}{l}\text { Mercuric bichloride } \\
\text { poisoning } \\
\text { F., } 46 \text { years, } 86 \mathrm{kgm} .\end{array}$ & & $\begin{array}{l}1 \\
2\end{array}$ & $\begin{array}{c}\text { grams } \\
15\end{array}$ & minutes & $\mid \begin{array}{c}c c \text {. per } \\
\text { minute } \\
0.1 \\
0.1\end{array}$ & 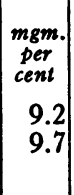 & $\begin{array}{c}\begin{array}{c}\mathrm{mgm} . \\
\text { per } \\
\text { cent }\end{array} \\
\\
438\end{array}$ & $\begin{array}{c}\text { mgm. } \\
\text { per } \\
\text { cent } \\
104 \\
108\end{array}$ & \begin{tabular}{|c|}
$c c$. \\
per \\
min- \\
ute \\
0.7 \\
0.4
\end{tabular} & $\begin{array}{c}c c . \\
\text { per } \\
\text { min- } \\
\text { ute } \\
\\
0.4\end{array}$ & $\begin{array}{c}c c . \\
p e r \\
\text { min- } \\
\text { ute } \\
0.3 \\
0.2\end{array}$ & 1.0 & 2.0 & $\begin{array}{l}2.3 \\
2.0\end{array}$ \\
\hline VII & $\begin{array}{l}\text { Acute glomerulonephritis } \\
\text { M., } 13 \text { years, } 42 \mathrm{kgm} \text {. }\end{array}$ & & $\begin{array}{l}1 \\
2 \\
3\end{array}$ & $(16) \ddagger$ & $\begin{array}{l}116 \\
150 \\
176\end{array}$ & $\begin{array}{l}2.6 \\
1.4 \\
1.3\end{array}$ & $\begin{array}{l}35.4 \\
30.5 \\
29.5\end{array}$ & $\begin{array}{l}228 \\
198 \\
186\end{array}$ & $\begin{array}{l}26.7 \\
28.0 \\
29.0\end{array}$ & $\begin{array}{l}59 \\
45 \\
36\end{array}$ & $\begin{array}{l}39 \\
25 \\
23\end{array}$ & $\begin{array}{l}26 \\
16 \\
15\end{array}$ & $\begin{array}{l}1.5 \\
1.8 \\
1.6\end{array}$ & $\begin{array}{l}1.5 \\
1.6 \\
1.5\end{array}$ & $\begin{array}{l}2.3 \\
2.8 \\
2.2\end{array}$ \\
\hline VIII & $\begin{array}{l}\text { Chronic glomerulonephritis, } \\
\text { terminal } \\
\text { M., } 54 \text { years, } 62 \mathrm{kgm} .\end{array}$ & $\begin{array}{l}\text { May } 12 \\
\text { May } 31\end{array}$ & \begin{tabular}{|l|}
1 \\
2 \\
3 \\
4 \\
1
\end{tabular} & 8 & $\begin{array}{r}78 \\
134 \\
175 \\
228 \\
80\end{array}$ & $\begin{array}{l}0.7 \\
0.7 \\
0.8 \\
0.9 \\
0.4\end{array}$ & \begin{tabular}{|l|}
22.4 \\
21.4 \\
18.3 \\
15.8 \\
23.5
\end{tabular} & $\begin{array}{l}77 \\
77 \\
73 \\
69 \\
40\end{array}$ & $\begin{array}{l}77.2 \\
77.1 \\
77.1 \\
77.4 \\
65.0\end{array}$ & $\begin{array}{l}6.6 \\
7.2 \\
8.7 \\
9.6 \\
3.0\end{array}$ & \begin{tabular}{|l|}
6.1 \\
6.1 \\
5.9 \\
6.5 \\
3.2
\end{tabular} & $\begin{array}{l}3.6 \\
4.0 \\
4.5 \\
7.8 \\
2.3\end{array}$ & \begin{tabular}{|l|}
1.1 \\
1.2 \\
1.5 \\
1.5 \\
1.0
\end{tabular} & \begin{tabular}{|l|}
1.7 \\
1.5 \\
1.3 \\
0.8 \\
1.4
\end{tabular} & $\begin{array}{l}1.9 \\
1.8 \\
1.9 \\
1.2 \\
1.3\end{array}$ \\
\hline IX & $\begin{array}{l}\text { Nephrosclerosis } \\
\text { F., } 45 \text { years, } 103 \text { kgm. }\end{array}$ & & $\begin{array}{l}1 \\
2\end{array}$ & 15 & $\begin{array}{l}111 \\
208\end{array}$ & $\begin{array}{l}3.5 \\
0.9\end{array}$ & $\begin{array}{l}23.8 \\
20.7\end{array}$ & $\begin{array}{l}143 \\
133\end{array}$ & $\begin{array}{l}20.4 \\
19.8\end{array}$ & $\begin{array}{r}100 \\
49\end{array}$ & $\begin{array}{l}66 \\
32\end{array}$ & $\begin{array}{l}43 \\
20\end{array}$ & $\begin{array}{l}1.5 \\
1.5\end{array}$ & $\begin{array}{l}1.5 \\
1.6\end{array}$ & $\begin{array}{l}2.3 \\
2.5\end{array}$ \\
\hline $\mathbf{x}$ & $\begin{array}{l}\text { Nephrosclerosis } \llbracket \\
\text { rheumatic heart disease } \\
\text { M., } 56 \text { years, } 54 \text { kgm. }\end{array}$ & & $\begin{array}{l}1 \\
2 \\
3 \\
4 \\
5 \\
6\end{array}$ & 10 & $\begin{array}{r}45 \\
81 \\
115 \\
162 \\
228 \\
315\end{array}$ & $\begin{array}{l}2.2 \\
1.8 \\
1.7 \\
1.0 \\
1.4 \\
1.7\end{array}$ & \begin{tabular}{|l|}
38.5 \\
32.8 \\
28.5 \\
27.0 \\
26.0 \\
24.2
\end{tabular} & & $\begin{array}{l}84.3 \\
84.0 \\
84.7 \\
83.3 \\
83.7 \\
83.9\end{array}$ & $\begin{array}{l}21.7 \\
19.1 \\
21.6 \\
15.0 \\
14.8 \\
17.8\end{array}$ & & \begin{tabular}{|r|}
9.8 \\
9.7 \\
10.2 \\
6.9 \\
8.1 \\
10.3 \\
\end{tabular} & & & $\begin{array}{l}2.2 \\
2.0 \\
2.1 \\
2.2 \\
1.8 \\
1.7\end{array}$ \\
\hline $\mathbf{X I}$ & $\begin{array}{l}\text { Acute glomerulonephritis } \\
\text { M., } 33 \text { years, } 98 \mathrm{kgm} \text {. }\end{array}$ & & $\begin{array}{l}1 \\
2 \\
3 \\
4 \\
5 \\
6 \\
7\end{array}$ & 10 & $\begin{array}{l}\text { Given } \\
\text { pre- } \\
\text { vious } \\
\text { night }\end{array}$ & $\begin{array}{l}1.0 \\
1.5 \\
1.2 \\
0.8 \\
0.7 \\
0.6 \\
0.5\end{array}$ & $\begin{array}{l}5.7 \\
5.7 \\
5.7 \\
5.7 \\
5.7 \\
5.7 \\
5.7\end{array}$ & $\begin{array}{l}360 \\
330 \\
320 \\
320 \\
315 \\
310\end{array}$ & $\begin{array}{l}\mathbf{5 6 . 2} \\
\mathbf{5 6 . 2} \\
\mathbf{5 6 . 2} \\
\mathbf{5 7 . 3} \\
\mathbf{5 7 . 4} \\
\mathbf{5 7 . 4} \\
\mathbf{5 7 . 3}\end{array}$ & $\begin{array}{l}22.8 \\
20.5 \\
17.7 \\
15.0 \\
14.1 \\
13.9 \\
12.7\end{array}$ & \begin{tabular}{|r}
17.8 \\
15.7 \\
12.1 \\
8.5 \\
8.8 \\
7.5
\end{tabular} & \begin{tabular}{|l|}
5.6 \\
7.1 \\
5.8 \\
3.3 \\
3.1 \\
1.9 \\
1.9
\end{tabular} & \begin{tabular}{|l|}
1.2 \\
1.1 \\
1.3 \\
1.7 \\
1.6 \\
1.7
\end{tabular} & $\begin{array}{l}2.5 \\
2.7 \\
3.7 \\
2.7 \\
4.6 \\
4.0\end{array}$ & $\begin{array}{l}4.1 \\
2.9 \\
3.1 \\
4.6 \\
4.6 \\
7.3 \\
6.7\end{array}$ \\
\hline
\end{tabular}

† $\mathrm{C}$ stands for creatinine, $\mathrm{S}$ for sucrose, and $\mathrm{U}$ for urea nitrogen. All times are calculated to the middle of the period, and all serum concentration figures are extrapolated values. Italic type indicates that the dose of creatinine was administered intravenously.

* 5.0 grams of urea in normal saline given intravenously in this period.

$\$ 8.0$ grams of creatinine given per os, followed almost immediately by vomiting; then 8.0 grams given intravenously.

It is possible that the nephrosclerosis was secondary to antecedent renal damage, since there was evidence of bilateral hydronephrosis by $\mathrm{x}$-ray.

volume these subjects behave as would subjects with entirely normal renal function. Also, the variation of the clearances together in a fixed order of magnitude is similar to the behavior of clearances in quite normal subjects.

In Table II, representing subjects with some definite reduction of clearances, there is no such decline of the creatinine clearance or of the creatinine: sucrose and creatinine: urea ratios with time (Figures $2 A$ and $2 B$ ). There are at least four other outstanding differences apparent in comparing this group with impaired clearances with the subjects of Table I, or with a normal group.

(1) The absolute numerical range of variation of the three clearances in any individual (in cc. per minute) is less than normal.
(2) The relative degree of variability (on a percentage basis) from period to period is much less.

(3) The clearance ratios, creatinine: urea, sucrose : urea, and creatinine: urea, in a given subject are much more constant than in a comparable subject with normal clearance levels.

(4) With marked reduction in the level of the clearances the creatinine:sucrose, sucrose:urea, and creatinine : urea ratios are smaller than usual, i.e., the clearances are nearer together. In two instances, the sucrose and creatinine clearances were identical.

An examination of the data shows that part of this stability of clearance is correlated with considerable stability of urine flow. This is doubtless 
an expression of the slow and relatively slight variation in urine flow which the nephritic with serious renal functional impairment shows in response to drinking water or other diuretic measures. However, in these low clearance cases there is some tendency for clearances and urine flow to vary simultaneously, as for example in Cases I and $\mathrm{X}$. continues to rise. This behavior resembles that of normal subjects.

(B) The relation of clearances to type of case (1) Nephritis.

(a) Acute nephritis (6 cases). Of these, two (Table I, Cases VI and IX) had recovered clini-

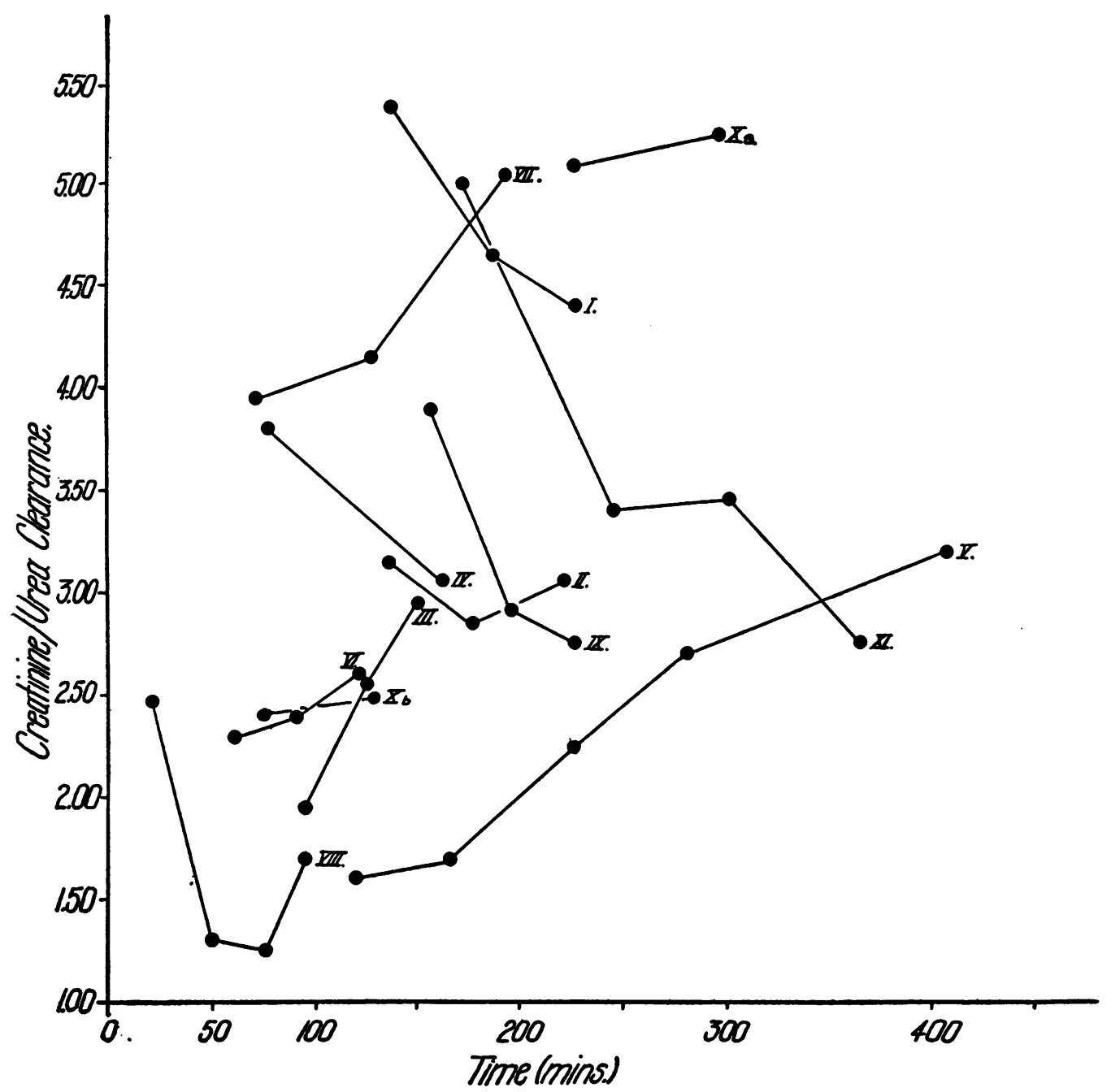

Fig. 1B. Variation of Creatinine: Urea Ratto with Time in Subjects without Depression of Clearances

The association of sudden increase in urine flow with transitory rise in the urea clearance is found in certain of the cases with depressed clearances. Thus in Experiment $\mathrm{V}$ the urea clearance increases with the rising urine flow between Periods 2 and 3 (July 8), and then falls back to its previous level in Period 4, although the urine flow cally, and all their clearances in absolute magnitude and in behavior are entirely normal. In one (Table II, Case VII), who later recovered completely after a fairly prolonged course, all clearances were depressed to about one-third normal at the time of this observation, some two weeks or so after the onset. They were entirely normal in 
their relations to one another at this time. No observations earlier or later were made. One ( $\mathrm{Ta}$ ble II, Case XI) went on to a fatal exitus from cerebral hemorrhage. His course was character-
Case $\mathrm{X}$ ) the initial observations were made within a few days after the onset of the nephritis. The first of these (Table II, Case V) had a very violent and explosive acute nephritis

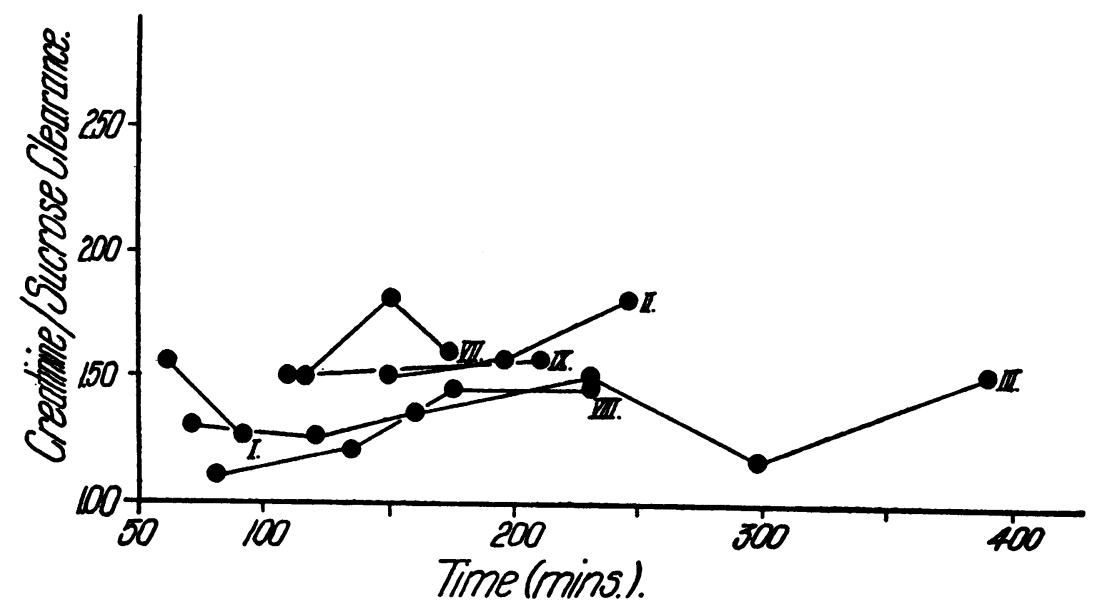

Fig. 2A. Variation of Creatinine: Sucrose Ratio with Time in Subjects with Depressed Clearances

ized by persistent and progressive oliguria, hypoproteinemia, albuminuria, edema, and elevation of blood nonprotein nitrogen concentration. There is merely a depression of all clearances to about one-tenth of their normal values. In the two remaining cases (Table II, Case V and Table I, with gross persistent hematuria, albuminuria and retinal hemorrhages. The first observation was made three days after the onset of hematuria. At this time although the serum urea nitrogen was 88 mgm. per cent and the urea clearance $5 \mathrm{cc}$. per minute, the creatinine clearance was almost

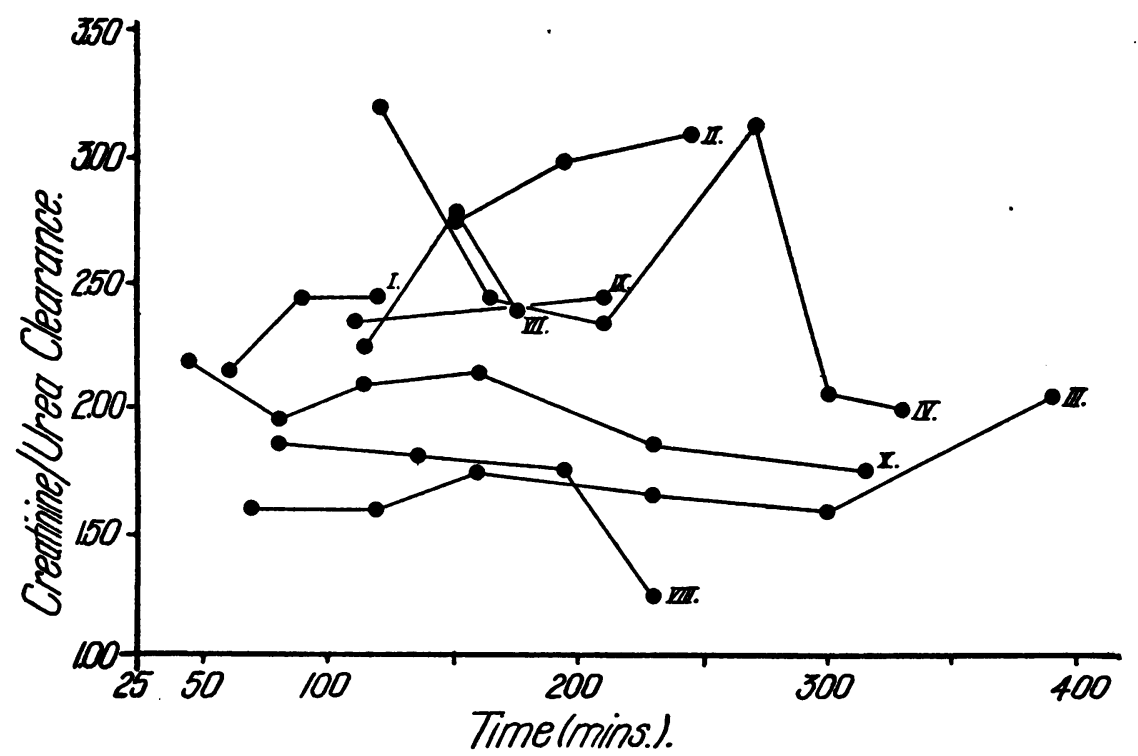

Fig. 2B. Variation of Creatinine: Urea Ratio with Time in Subjects with Depressed Clearances 
normal (about 100 cc. per minute). During the next few months the patient improved considerably but did not clear up entirely, and now one year later presents a picture of subacute or chronic active glomerulonephritis. In the month following the initial observation the creatinine clearance fell and the urea clearance rose until they stood in a normal relation to one another but both at depressed levels. The continued depression thereafter is correlated with continuance of the active process. The second case of acute nephritis (Table I, Case X) was first studied about a week or more after the onset of hematuria. The course was much more benign than the one just described; within a few days the hematuria and albuminuria virtually disappeared. At the time of the initial observations, however, creatinine clearance was very high, both absolutely and relative to the sucrose and the urea clearances, and in this respect the reaction is comparable to that of the preceding case. This impression is strengthened by the fact that the repeated determination of the three clearances after subsidence of the acute process shows a lower creatinine: sucrose and a much lower creatinine: urea ratio, both ratios being now quite within the normal range.

\section{(2) Chronic nephritis (9 cases).}

(a) "Lipoid nephrosis" without vascular disease ( 2 cases, Table I, Cases III and IV). These were both 16 year old girls who suddenly developed massive proteinuria, with leukocytes and casts in the urine sediment, hypoproteinemia and lipemia, and generalized edema, without hematuria or vascular disease. Clearances were entirely normal in magnitude and in behavior, including the fall of the creatinine clearances with time. These are the only subjects with definite chronic renal disease who had normal clearances.

(b) Chronic nephritis with vascular disease (7 cases, Table II, Cases I, III, IV, VIII, IX, X and Table I, Case XI). These cases present all degrees of reduction of clearances down to one-tenth or even one-twentieth of normal. In all, the clearances and urine flow are relatively fixed and in most the ratios between clearances are lower than normal. The three cases with creatinine clearances less than $20 \mathrm{cc}$. per minute all died within a few weeks. The single observation of Case VIII on May 31, 1935, was made a few days before death, and is one of the two observations in which the sucrose and creatinine clearances are identical.

(c) Chronic pyelonephritis (infection with $B$. coli) ( 1 case, Table II, Case II). This was a case of chronic ascending pyelonephritis in a female subject with probable secondarily contracted kidneys. As in chronic nephritis of the vascular type, the clearances are uniformly depressed and vary but little from period to period.

\section{(3) Mercury poisoning (1 case, Table II, Case $V I)$.}

These clearances were determined on the ninth day of $\mathrm{HgCl}_{2}$ poisoning in a woman who died three days later. After two or three days of initial anuria following the ingestion of the poison the patient began passing very small amounts of urine, without any tendency to increase the volume in the succeeding days. The second clearance was obtained between two catheterizations and is thus exact. It is the lowest clearance in the series, and is the second of the two instances in which the creatinine and sucrose clearances were identical. Even here the urea clearance is definitely lower than the other two.

\section{(4) Vascular disease without evidence of renal disease (4 cases).}

(a) Generalized arteriosclerosis ( 3 cases, Table I, Cases II, V, and VII). In two of the three cases the clearances though still in the normal range, are very close to the lower limits of normal. In the remaining case they are entirely normal.

(b) Hypertension following toxemia of pregnancy ( 1 case, Table I, Case I). In this case the clearances are entirely normal in magnitude and behavior.

\section{(5) Diabetes insipidus ( 1 case, Table I, Case $V I I I)$.}

While the clearance of creatinine is quite normal, that of urea is supra-normal, reaching at one time $159 \mathrm{cc}$. per minute, the highest in this series and higher than any true normal. It is associated with the abnormally high urine volume of $26 \mathrm{cc}$. per minute. 


\section{DISCUSSION}

Data secured from such a wide variety of pathological states as are here represented are apt to raise more questions than they answer. All the more remarkable then does it seem that the order of clearances, creatinine $>$ sucrose $>$ urea, should have been so regularly maintained with such a range of material and under such varying conditions. In only a certain number of instances were the ratios of the clearances to one another outside the usual range. A peculiarly fundamental physiological significance of these clearances is indicated by the fact that their magnitude alone should be affected in the most varied types of renal damage.

The exceptions to the rule are of peculiar interest. The two instances in which creatinine and sucrose clearances were equal, are also the two with the lowest clearances. Both patients had kidneys which were so badly impaired that death ensued from renal failure within a few days. Even in these cases the urea clearance was appreciably lower than the other two, perhaps because passive back diffusion persisted as long as any filtration whatsoever continued. Cambier (1) in one case of $\mathrm{HgCl}_{2}$ poisoning with recovery found the urea and creatinine clearances identical at first. They gradually diverged as the patient recovered until they returned to their normal relationship to one another. The observations in our case were made some days after urine flow had recommenced, and so are not comparable. The tendency of cases with advanced renal disease to have the three clearances closer together than normal is also noteworthy and probably indicates that with increasing renal damage, tubular secretion of creatinine as well as reabsorption of sucrose and urea diminish.

High creatinine and low urea clearances in the early stages of acute nephritis may indicate that tubular secretion of creatinine is increased at this early stage of the disease. An alternative interpretation, persistently high filtration with increased reabsorption of urea, is possible. However, the hypothesis of tubular secretion seems somewhat more probable in view of the fact that the sucrose clearance is aligned with the urea rather than with the creatinine clearance. Furthermore, Goldring (4) has recently demonstrated that in this same early stage of acute nephritis, the phenol red clearance is disproportionately elevated, again indicating excessive tubular secretory activity under these special circumstances.

The two cases with nephrosis show a quite intact tubular " secretory" mechanism, if the fall of creatinine clearance with time may be so interpreted. This is entirely consistent with the ability of these patients to concentrate urine to a high degree, and to reabsorb salt completely. The absence of any reduction in the magnitude of the clearances, furthermore, indicates an intact glomerular filtration rate; so apparently the nephrotic state might be explained by a slightly increased permeability of the glomerular membrane which allows albumin (but very little globulin and no red cells) to pass by it along with the ultrafiltrable solution. This does not seem consistent with the demonstration that the chief cellular pathology exists in the tubular cells (10), but no ready explanation of this paradox is at present forthcoming.

Taking all these regularities and occasional exceptions together the thesis that all three clearances in general are measures of glomerular filtration is strengthened. Such regular behavior may be accounted for easily on such a basis and upon no other.

The fact that the badly damaged kidneys did not show the peculiar drop of the creatinine clearance with time, whereas those without impairment of clearance behaved like normals, would support the view that this peculiar effect is renal in origin, without pointing to the particular part of the kidney responsible for it.

The significance of this study in elucidating the phenomena of renal damage is chiefly incidental. Our results confirm and supplement the findings of Holten and Rehberg $(6,7)$, Ellis and Weiss (3), Hayman et al. (5), Cope (2), Cambier (1), and others who have studied creatinine and urea clearances simultaneously and have in general found them impaired to a parallel degree in renal disease. In the light of the filtration interpretation of clearance this must mean that usually in renal disease when glomerular filtration is reduced, reabsorption of urea is correspondingly impaired. The most reasonable interpretation of such a consistent effect is that the number of 
glomeruli filtering at any time is reduced in renal disease, but that those glomeruli which are actively filtering are associated with tubule cells which reabsorb nearly their usual percentage of urea. Shannon (8) and others have suggested that in the intact kidney urea is reabsorbed both by passive diffusion and by cellular activity in the tubules. The example of extreme depression of clearances in which the urea clearance is closer than usual to the creatinine could be readily explained with such a dual theory by assuming that with progressive renal damage the active power to reabsorb urea is lost, leaving a certain measure of back diffusion only. Such an interpretation must however needs be quite hypothetical until it can be decided whether two such mechanisms actually exist in the intact kidney. Our observations do not bear on this most fundamental point, so the question of definite interpretation of the lowering of the creatinine : urea clearance ratios in advanced renal disease must await other experience.

\section{CONCLUSIONS}

1. The behavior of the creatinine, sucrose, and urea clearances in subjects with various renal and vascular diseases differs somewhat from their behavior in normal subjects.

2. In the presence of definite renal disease the absolute magnitude of all three clearances is usually consistently and uniformly reduced, while the normal order of the clearances, creatinine $>$ sucrose $>$ urea is in general maintained.

3. In "nephrosis" all of the clearances may be normal in magnitude and behavior.

4. In the early stages of acute nephritis the creatinine clearance may be disproportionately high.

5. The falling off of the creatinine clearance with time, which is seen in normal subjects, is not to be found in subjects with depressed clearances.

6. In subjects with depressed clearances the absolute and relative variability of the clearances is reduced, as are the numerical values of the ratios of the clearances to one another.

7. The behavior of these clearances in the presence of renal disease is consistent with the belief that as in the normal subject they are all relative measures of filtration. Their behavior is also consistent with the theory that the degree of reduction of these clearances reflects quantitatively the degree of reduction of the glomerular filtration rate.

\section{BIBLIOGRAPHY}

1. Cambier, Pierre, Application de la théorie de Rehberg a l'étude clinique des affections rénales et du diabète. II. La fonction rénale chez les sujets normaux et chez les néphrétiques. Ann. de méd., 1934, 35, 196.

2. Cope, C. L., The excretion of creatinine by the human kidney in health and in nephritis. Quart. J. Med., 1931, 24, 567.

3. Ellis, L. B., and Weiss, S., The renal function in persons with one kidney. Am. J. M. Sc., 1933, 186, 242.

4. Goldring, W., Personal communication.

5. Hayman, J. M., Jr., Halsted, J. A., and Seyler, L. E., A comparison of the creatinine and urea clearance tests of kidney function. J. Clin. Invest., 1933, 12, 861.

6. Holten, C., and Rehberg, P. B., Studies on the pathological function of the kidneys in renal disease, especially Bright's disease. I. Acta med. Scandinav., 1931, 74, 479.

7. Holten, C., and Rehberg, P. B., Studies on the pathological function of the kidneys in renal disease, especially Bright's disease. II. Acta med. Scandinav., 1931, 74, 538.

8. Shannon, J. A., Glomerular filtration and urea excretion in relation to urine flow in the dog. Am. J. Physiol., 1936, 117, 206.

9. Winkler, A. W., and Parra, J., The measurement of glomerular filtration. The creatinine, sucrose and urea clearances in subjects without renal disease. J. Clin. Invest., 1937, 16, 000.

10. Van Slyke, D. D., Stillman, E., Möller, E., Ehrich, W., McIntosh, J. F., Leiter, L., MacKay, E. M., Hannon, R. R., Moore, N. S., and Johnston, C., Observations on the courses of different types of Bright's disease, and on the resultant changes in renal anatomy. Medicine, 1930, 9, 257. 